\title{
Vacuum-Packaged Precooked Pork from Hogs Fed Supplemental Vitamin E: Chemical, Shelf-Life and Sensory Properties
}

\author{
J.E. CANNON, J.B. MORGAN, G.R. SCHMIDT, R.J. DELMORE, J.N. SOFOS, G.C. SMITH, and S.N. WILLIAMS
}

\begin{abstract}
Precooked longissimus chops and semimembranosus/adductor roasts from pigs $(n=30)$ given no supplemental vitamin $E(C O N)$ or supplemented with $100 \mathrm{mg}$ vitamin E/ $\mathrm{kg}$ diet (VITE) were evaluated for lipid oxidation, microbial growth, sensory characteristics, cooking/storage losses and reheating losses. Chops and roasts were vacuum packaged, precooked to $60^{\circ} \mathrm{C}$ and stored at $2^{\circ} \mathrm{C}$ for $0,7,14,28$, or 56 days. Lipid oxidation was lower in VITE chops and roasts than in CON chops and roasts. Off-flavor intensity scores were more acceptable and storage/ cooking losses were lower for VITE roasts than for CON roasts. Supplementation of vitamin $\mathrm{E}$ in a swine diet provided added protection against lipid oxidation and precooking pork under vacuum provided a palatable product with a shelf-life of $\geq 56$ days.
\end{abstract}

Key Words: precooked pork, vitamin E, shelf-life, vacuum packaged

\section{INTRODUCTION}

A PROBLEM associated with precooked/stored/reheated meat is warmed-over flavor (WOF), caused by oxidation of lipids (Tims and Watts, 1958). Such oxidation greatly reduces consumer acceptability because of associated rancid flavors (Cross et al., 1987). Warmed-over flavor is an important factor in manufacturing and marketing precooked meat products.

Dietary vitamin E ( $\alpha$-tocopherol) may be useful as an antioxidant for meat that is to be precooked. Vitamin $E$ inactivates frec radicals in cell membrancs, thus inhibiting oxidation of phospholipids, the primary source of WOF (Coelho, 1991). Previous studies have shown that lipid oxidation was inhibited in cooked and stored poultry (Lin et al., 1989; Ajuyah et al., 1993) and pork (Monahan et al., 1990a,b, 1992b) when the meat was from animals fed supplemental vitamin $E$. Successful inhibition of WOF by dietary supplementation of vitamin $E$ would enable production of precooked meat products with acceptable shelflife and sensory characteristics.

Our objective was to determine the influence of supplemental vitamin $\mathrm{E}$, fed to pigs for 84 days prior to slaughter, on lipid oxidation, shelf-life and sensory characteristics of pork precooked using cook-in-bag technology.

\section{MATERIALS \& METHODS}

\section{Feeding regimen}

The dietary treatments and feeding period of the pigs were reported in Cannon et al. (1995). Briefly, 30 crossbred pigs were assigned to five pen blocks based on weight. Within each block, pigs were randomly allotted to one of two treatment groups: (1) a control diet containing no supplementary vitamin $\mathrm{E}(\mathrm{CON})$ and (2) a diet formulated to contain $100 \mathrm{mg} / \mathrm{kg}$ diet supplementary vitamin E (VITE). After an 84 day feeding period, pigs were slaughtered using commercial procedures.

\section{Precooked chop study}

At 4 days postmortem, loins from the right side of each carcass were removed, deboned and trimmed to no more than $0.31 \mathrm{~cm}$ of external fat.

Authors Morgan, Schmidt, Delmore, Sofos, and Smith are with the Dept. of Animal Sciences, Colorado State Univ., Ft. Collins, 80523. Author Cannon's present address: DEKALB Swine Breeders, DeKalb, IL 60115. Author Williams is with Hoffman-LaRoche, Inc., Nutley, NJ 07110-1199. Address inquiries to Dr. G.R. Schmidt.
Each loin was sliced into $2.54 \mathrm{~cm}$ chops and randomly assigned to five vacuum storage times (three chops/storage time) of $0,7,14,28$, or 56 days. Three chops/storage group were packaged together, under vacuum $(-0.8 \mathrm{bar})$, in cook-in-bags (CN-530; oxygen transmission rate, $20 \mathrm{cc} /$ $\mathrm{m}^{2} / 24 \mathrm{hr}, 1$ atm @ $22.8^{\circ} \mathrm{C}$ and $0 \% \mathrm{RH}$; Cryovac Division, W.R. Grace and Company, Ft. Worth, TX). Chops were steam-cooked in a commercial oven (Alkar Model 450, Alkar, Lodi, WI) to internal temperature $60^{\circ} \mathrm{C}$, showered $\left(21^{\circ} \mathrm{C}\right)$ for $10 \mathrm{~min}$ and then stored in the absence of light at $2^{\circ} \mathrm{C}$ for the specified storage period. Loin chops assigned to the 0 days storage period were evaluated after a $24 \mathrm{hr}$ cooling perind. Lipid oxidation determination, total plate count (TPC), sensory analysis, $\mathrm{pH}$, cooking/storage losses and reheating losses were evaluated at each storage time. Cooking/storage losses were determined from wcights recorded prior to packaging and immediately after removal from the package.

Lipid oxidation was determined using thiobarbituric acid (TBA) analysis procedures of Salih et al. (1987), with the modification of $5 \%(\mathrm{w} /$ v) aqueous trichloroacetic acid as the extraction solvent instead of perchloric acid (Raharjo et al., 1993). Results were expressed as TBA values (mg malonaldehyde/kg wet tissue).

Duplicate samples for microbial evaluation were obtained by aseptically removing $10 \mathrm{~g}$ tissue samples and placing them into stomacher bags containing $90 \mathrm{~mL}$ of a sterile $0.1 \%$ peptone water solution. Samples were placed into a stomacher apparatus (Stomacher Lab-Blender 400, Tekmar Company, Cincinnati, $\mathrm{OH}$ ) and homogenized for $2 \mathrm{~min}$. Appropriate serial dilutions were made in sterile peptone water and $0.1 \mathrm{~mL}$ of each diluent were spread onto total plate count (TPC) agar (Bacto $\mathrm{Nu}-$ trient Agar, Difco Laboratories, Detroit, MI). Plates were incubated at $25^{\circ} \mathrm{C}$ for $48 \mathrm{hr}$ and bacteria colonies were counted. The $\mathrm{pH}$ of the blended samples was determined at each sampling time using an Accumet $\mathrm{pH}$ meter 50 (Fisher Scientific, Pittsburgh, PA).

Chops for sensory evaluation were reheated on Farberware openhearth grills (Farberware Model 155N, Walter Kidde, Inc., Bronx, NY) to internal temperature $70^{\circ} \mathrm{C}$ monitored by a thermocouple (Atkins Technical Inc., Gainesville, FL). Chops were turned once at $35^{\circ} \mathrm{C}$ to prevent charring. Immediately after reheating, cubed portions from each chop were served to a 6-member trained sensory panel for evaluation of tenderness, juiciness, pork flavor intensity and off-flavor intensity. The taste panel members had previous sensory evaluation experience. The panel was given an additional 4-day training period where they evaluated precooked pork which had been stored for extended periods of time, to

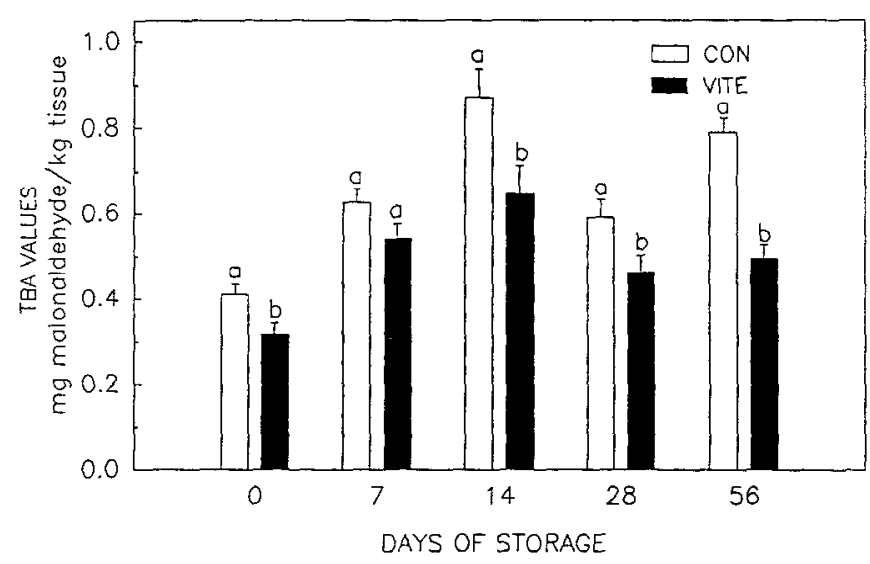

Fig. 1-TBA values for precooked chops from controls and pigs supplemented with vitamin $E$. The following model effects were observed: Treatment $={ }^{*}$, Storage $={ }^{*}$ and Treatment $\times$ Storage interaction $=^{*}$; where ${ }^{*}=\mathrm{P}<0.05$ and $\mathrm{NS}=$ not significant. $a, b$ Treatment means within the same storage period lacking a common superscript letter differ $(P<0.05)$. 
Table 1-Sensory properties of precooked chops stored 7 to 56 days from controls and pigs supplemented with vitamin $\mathrm{E}^{\mathrm{a}}$

\begin{tabular}{|c|c|c|c|c|c|}
\hline \multirow{2}{*}{$\begin{array}{l}\text { Trait }^{\mathrm{b}} \text { and } \\
\text { treatment }^{\mathrm{c}}\end{array}$} & \multicolumn{4}{|c|}{ Days } & \multirow{2}{*}{$\begin{array}{l}\text { Model } \\
\text { effects }^{d}\end{array}$} \\
\hline & 7 & 14 & 28 & 56 & \\
\hline \multicolumn{6}{|l|}{ Juiciness } \\
\hline CON & 5.63 & 6.47 & 4.55 & 6.42 & Trt: NS \\
\hline VITE & 4.87 & 6.71 & 5.35 & 5.66 & Stor* \\
\hline SEM ${ }^{e}$ & 0.304 & 0.268 & 0.388 & 0.329 & TrtxStor* \\
\hline \multicolumn{6}{|l|}{ Tenderness } \\
\hline CON & 7.91 & 8.14 & 7.84 & 8.71 & Trt: NS \\
\hline VITE & 8.37 & 8.56 & 8.33 & 8.20 & Stor: NS \\
\hline SEM & 0.257 & 0.209 & 0.265 & 0.337 & TrtxStor NS \\
\hline \multicolumn{6}{|c|}{ Pork-flavor intensity } \\
\hline CON & 7.43 & 7.32 & 7.18 & 7.36 & Trt: NS \\
\hline VITE & 7.64 & 7.55 & 7.28 & 7.01 & Stor: NS \\
\hline SEM & 0.176 & 0.130 & 0.194 & 0.207 & TrtxStor NS \\
\hline \multicolumn{6}{|c|}{ Off-flavor intensity } \\
\hline CON & 14.45 & 14.26 & 13.83 & 13.99 & Trt: NS \\
\hline VITE & 14.83 & 14.55 & 14.03 & 13.91 & Stor* \\
\hline SEM & 0.157 & 0.116 & 0.162 & 0.208 & TrtxStor NS \\
\hline
\end{tabular}

a No statistical differences were observed for 0 days and 7 days comparisons.

b Sensory measurements using a $15 \mathrm{~cm}$ line scale; $0 \mathrm{~cm}=$ extremely dry, tough, bland and intense off-flavor; and $15 \mathrm{~cm}=$ extremely juicy, tender, intense pork-flavor and no off-flavor.

c CON = control diet; VITE = diet supplemented with vitamin $E$.

d Repeated measures model effects: Trt = treatment, Stor $=$ storage period, TrtxStor $=$ treatment by storage interaction; ${ }^{*}=P<0.05$, NS = not significant.

e Standard error of least squares means for storage within treatment.

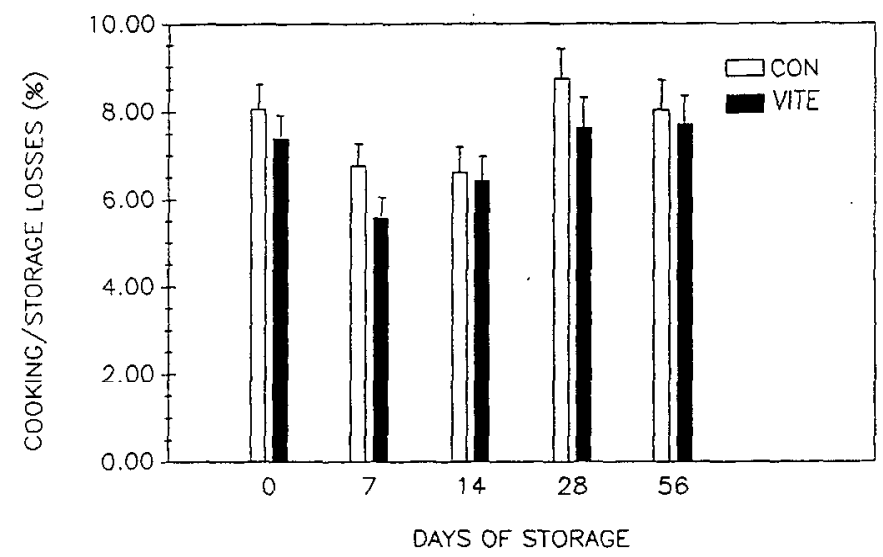

Fig. 2-Cooking/storage losses for precooked chops from controls and pigs supplemented with vitamin $E$. The following model effects were observed: Treatment $=$ NS, Storage $={ }^{*}$ and Treat ment $\times$ Storage interaction $=$ NS; where ${ }^{*}=\mathrm{P}<0.05$ and NS $=$ not significant.

familiarize them with changes that occur in pork during storage, specifically development of warmed-over flavor (WOF). Panelists used a 15 $\mathrm{cm}$ line scale with anchors and a midpoint $(0 \mathrm{~cm}=$ extremely dry, tough, bland and intense off-flavor; $15 \mathrm{~cm}=$ extremely juicy, tender, intense pork-flavor and no off-flavor). Samples $\left(70^{\circ} \mathrm{C}\right)$ were served with water $\left(25^{\circ} \mathrm{C}\right)$ to members of the taste panel in a room where red lighting was used. Only five chops from each treatment were evaluated at 0 days compared to 15 chops/treatment evaluated at other sampling times. Reheating losses were determined by weighing samples before and after reheating. At 0 days, the same five chops from each treatment group used for sensory analysis were evaluated for reheating loss.

Proximate analysis was conducted on longissimus muscle from the chops used for the zero day evaluation. Closely-trimmed longissimus muscle samples were prepared by homogenizing in a food blender. Duplicate 3-g samples were used to evaluate moisture and lipid content using an oven drying procedure $\left(70^{\circ} \mathrm{C}\right.$ for $12 \mathrm{hr}$ in a vacuum oven) and repetitive washes of petroleum ether in a Soxhlet extraction apparatus (AOAC, 1990)

\section{Precooked roast study}

At 4 days postmortem, closely trimmed semimembranosus/adductor muscles were removed from both fresh hams $(n=60)$ of each carcass and were used to represent a product prepared as a roast. Roasts were
Table 2-Total plate count (log CFU/g) of precooked chops and roasts from controls and pigs supplemented with vitamin $\mathrm{E}$

\begin{tabular}{|c|c|c|c|c|c|c|}
\hline \multirow{2}{*}{$\begin{array}{l}\text { Trait and } \\
\text { treatment }\end{array}$} & \multicolumn{5}{|c|}{ Days } & \multirow{2}{*}{$\begin{array}{l}\text { Model } \\
\text { effects }^{b}\end{array}$} \\
\hline & 0 & 7 & 14 & 28 & 56 & \\
\hline \multicolumn{7}{|c|}{ Precooked chops } \\
\hline CON & 2.01 & 3.12 & 1.91 & 2.77 & 3.00 & Trt NS \\
\hline VITE & 2.14 & 3.08 & 1.97 & 2.66 & 3.02 & Stor* \\
\hline SEM $^{\mathrm{C}}$ & 0.081 & 0.080 & 0.039 & 0.257 & 0.013 & TrtxStor NS \\
\hline \multicolumn{7}{|c|}{ Precooked roasts } \\
\hline CON & $1.91^{x}$ & 3.00 & $1.96^{x}$ & 1.94 & 3.00 & Trt* \\
\hline VITE & $2.57 y$ & 3.00 & $2.43 y$ & 1.88 & 3.00 & Sitor* \\
\hline SEM & 0.122 & 0.122 & 0.122 & 0.122 & 0.122 & TrtxStor* \\
\hline
\end{tabular}

${ }^{a}$ CON $=$ control diet: VITE $=$ diet supplemented with vitamin $E$.

Repeated measures model effects: Trt $=$ treatment, Stor $=$ storage pfiriod, TrtxStor $=$ treatment by storage interaction; ${ }^{*}=P<0.05$, NS $=$ not significant.

c Standard error of least squares means for storage within treatment.

$x, y$ Means in the same column within each trait lacking a common superscript letter differ $\langle P<0.05\rangle$.

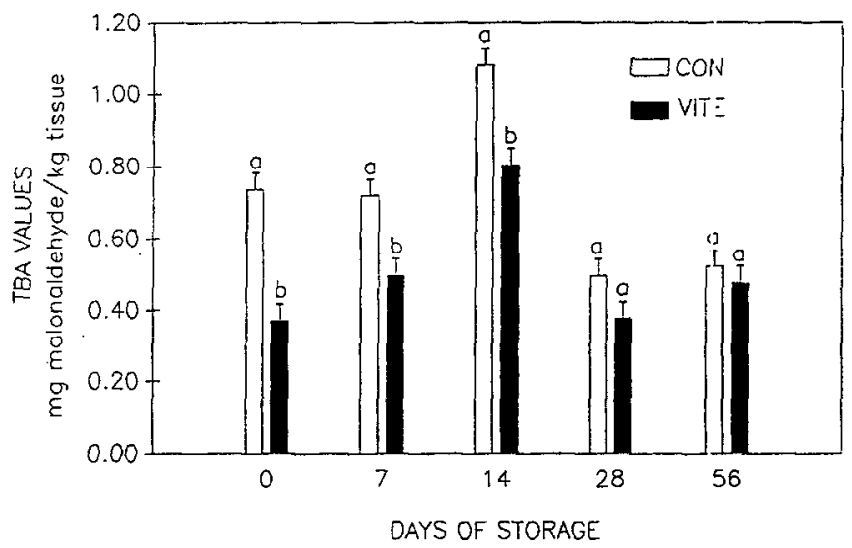

Fig. 3-TBA values for precooked roasts from controls and pigs supplemented with vitamin $\mathrm{E}$. The following model effects were observed: Treatment $=*$, Storage $={ }^{*}$ and Treatment $\times$ Storage interaction $=*$; where ${ }^{*}=\mathrm{P}<0.05$ and $\mathrm{NS}=$ not significant. $a, b$ Treatment means within the same storage period lacking a common superscript letter differ $(P<0.05)$.

vacuum packaged ( -0.8 bar) in cook-in-bags (CN-530, Cryovac Division, W.R. Grace \& Company, Ft. Worth, TX). Packaged roasts were steam-cooked to internal temperature $60^{\circ} \mathrm{C}$ and showered $\left(21^{\circ} \mathrm{C}\right)$ for 10 min. Roasts were randomly assigned, by treatment, to five storage times of $0,7,14,28$, or 56 days. Roasts were held at $2^{\circ} \mathrm{C}$ for the specified storage period. Roasts assigned to the 0 days storage period were evaluated after a $24 \mathrm{hr}$ cooling period. Sensory evaluation, T'BA analysis, TPC, $\mathrm{pH}$, storage losses and reheating losses were determined at the end of each storage period.

Cooking/storage losses were determined from weights recorded prior to packaging and immediately after removal of roasts from opened packages. Cooking/storage losses were not calculated for the product evaluated at 0 days. To provide enough pork for the entire experiment, roasts were cut into $2.54 \mathrm{~cm}$ slices at specified storage periods, and TBA, TPC and $\mathrm{pH}$ measurements were determined using procedures described for the precooked chop study. Tissue $\mathrm{pH}$ values were not obtained for samples stored for 7 days.

Taste panel slices were reheated in a Hobart Model DN 97-19 convection oven (Hobart Corporation, Troy, $\mathrm{OH}$ ) at $149^{\circ} \mathrm{C}$ to internal temperature $70^{\circ} \mathrm{C}$. Sensory evaluation was conducted employing procedures used for precooked chops. Reheating losses were determined by weighing slices prior to and immediately after heating.

Proximate analyses were conducted on duplicate $3-\mathrm{g}$ : samples taken from one precooked roast from each carcass. Moisture and lipid contents were determined using the same procedures as for the precooked loin chop study.

\section{Statistical analysis}

Individual taste panel scores were averaged across panelists using least squares means. All data were analyzed using the General Linear Model procedures of SAS Institute, Inc. (1986). For the precooked chop study, TBA, TPC, pH, cooking/storage losses, reheating losses and taste panel 
Table 3-Sensory properties of precooked roasts from controls and pigs supplemented with vitamin $\mathrm{E}$

\begin{tabular}{|c|c|c|c|c|c|c|}
\hline \multirow{2}{*}{$\begin{array}{l}\text { Trait }{ }^{a} \text { and } \\
\text { treatment }^{b}\end{array}$} & \multicolumn{5}{|c|}{ Days } & \multirow{2}{*}{$\begin{array}{l}\text { Model } \\
\text { effects }\end{array}$} \\
\hline & 0 & 7 & 14 & 28 & 56 & \\
\hline Juiciness & & & & & & Trt NS \\
\hline $\begin{array}{l}\text { CON } \\
\text { VITE }\end{array}$ & $\begin{array}{l}8.34 \\
8.34\end{array}$ & $\begin{array}{l}8.81 \\
9.53\end{array}$ & $\begin{array}{l}7.12 \\
7.85\end{array}$ & $\begin{array}{l}3.92 \\
4.29\end{array}$ & $\begin{array}{l}6.83 \\
6.20\end{array}$ & $\begin{array}{l}\text { Stor* } \\
\text { TrtxStor NS } \\
\text { SEM }^{d}=0.514\end{array}$ \\
\hline $\begin{array}{l}\text { Tenderness } \\
\text { CON } \\
\text { VITE }\end{array}$ & $\begin{array}{l}7.83^{x} \\
9.00^{y}\end{array}$ & $\begin{array}{l}8.42^{x} \\
9.73^{y}\end{array}$ & $\begin{array}{l}7.71 x \\
8.97 y\end{array}$ & $\begin{array}{l}7.64 \\
8.34\end{array}$ & $\begin{array}{l}8.53 \\
7.94\end{array}$ & $\begin{array}{l}\text { Trt }{ }^{*} \\
\text { Stor } P=0.08 \\
\text { TrtxStor } P=0.09 \\
\text { SEM }=0.386\end{array}$ \\
\hline $\begin{array}{l}\text { Pork-flavor it } \\
\text { CON } \\
\text { VITE }\end{array}$ & $\begin{array}{r}\text { sity } \\
7.14 \\
7.28\end{array}$ & $\begin{array}{l}7.41 \\
7.46\end{array}$ & $\begin{array}{l}7.50 \\
7.54\end{array}$ & $\begin{array}{l}7.85 \\
7.74\end{array}$ & $\begin{array}{l}7.29 \\
7.44\end{array}$ & $\begin{array}{l}\text { Trt NS } \\
\text { Stor NS } \\
\text { TrtxStor NS } \\
\text { SEM }=0.272\end{array}$ \\
\hline $\begin{array}{l}\text { Off-flavor int } \\
\text { CON } \\
\text { VITE }\end{array}$ & $\begin{array}{l}y \\
14.26 \\
14.86\end{array}$ & $\begin{array}{l}13.56 \\
14.25\end{array}$ & $\begin{array}{l}14.33 \\
14.49\end{array}$ & $\begin{array}{l}13.24 \\
14.00\end{array}$ & $\begin{array}{l}13.77 \\
14.40\end{array}$ & $\begin{array}{l}\text { Trt* } \\
\text { Stor* } \\
\text { TrtxStor NS } \\
\text { SEM }=0.278 \\
\end{array}$ \\
\hline
\end{tabular}

a Sensory measurements using a $15 \mathrm{~cm}$ line scale; $0 \mathrm{~cm}=$ extremely dry, tough, bland intense off-flavor and unpalatable; and $15 \mathrm{~cm}=$ extremely juicy, tender, intense porkflavor, no off-flavor and palatable.

b $\mathrm{CON}=$ control diet; VITE = diet supplemented with vitamin E.

c Model effects: Trt $=$ treatment, Stor $=$ storage period, TrtxStor $=$ treatment by storage interaction: $*=P<0.05$. NS $=$ not significant.

d Standard error of least squares means for treatment $x$ storage effects.

$x, y$ Means in the same column for each trait lacking a common superscript letter differ $(\mathrm{P}<0.05)$

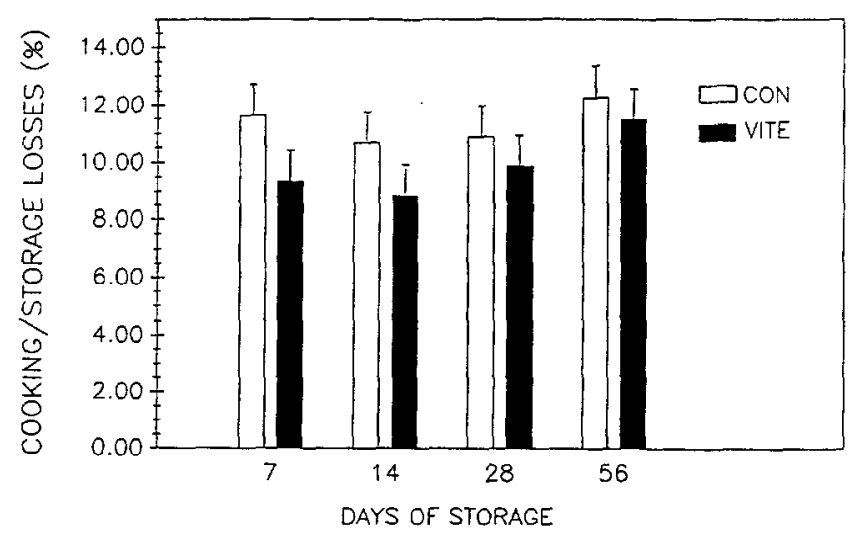

Fig. 4-Cooking/storage losses for precooked roasts from controls and pigs supplemented with vitamin $E$. The following model effects were observed: Treatment $=P=0.05$, Storage $=$ NS and Treatment $\times$ Storage interaction $=$ NS; where ${ }^{*}=\mathrm{P}<0.05$ and NS = not significant.

data were analyzed using a repeated measures model that included the fixed effect of treatment and storage period as a repeated measure. Because only 10 chops were evaluated for sensory characteristics and reheating loss at zero days storage, two repeated measures analyses were conducted. One analysis compared chops used at 0 days to those same chops at 7 days and the other compared sensory evaluations and reheating losses of chops determined at 7, 14, 28 and 56 days storage.

Data for precooked roasts (TBA, TPC, $\mathrm{pH}$, reheating losses, storage losses and taste pancl evaluations) werc analyzed using a completely randomized design. The model included the fixed effects of treatment and storage period, and interactions between the two effects. Lipid and moisture data for the chop study and roast study were analyzed using a complete randomized block design. The block design utilized the pen blocks of the feeding period (Cannon et al., 1995) to account for weight variation in the pigs.

\section{RESULTS \& DISCUSSION}

THE MOST IMPORTANT TRAIT affecting acceptability and, thus, marketability of precooked pork products is the presence/absence of rancid flavor (WOF) associated with lipid oxidation (Tims and Watts, 1958). The processing and ingredients used to manufacture precooked pork products are critical in minimizing lipid oxidation. Supplementing pigs with vitamin $E$ during the finishing period yielded pork that was less susceptible-as fresh and cooked product-to lipid oxidation during storage (Monahan et al., 1990a,b; 1992b). In our previous studies (Cannon et al., 1995), $\alpha$-tocopherol was 10 -fold higher $(P<0.05)$ in longissimus muscle from pigs supplemented with vitamin $\mathrm{E}$ (1.86 $\pm 0.20 \mu \mathrm{g} / \mathrm{g}$ tissue) than in that from pigs on a control diet $(0.19 \pm 0.03 \mu \mathrm{g} / \mathrm{g}$ tissue). From those results, we concluded that vitamin $E$ was effectively incorporated into muscle through supplementation in growing and finishing diets.

\section{Precooked chop study}

Percentage moisture and percentage lipid as well as $\mathrm{pH}$ were not different $(\mathrm{P}>0.05)$ for precooked chops from pigs supplemented with vitamin $\mathrm{E}$ as compared to those from pigs fed controls (data not presented in tabular form). Lipid oxidation, by TBA values, was consistently lower $(\mathrm{P}<0.05)$ for VITE chops than for CON chops (Fig. 1). Lower TBA values for cooked chops from pigs fed supplemental vitamin $E$ agreed with Monahan et al. (1990a,b) who stored cooked chops for times shorter than ours. A significant storage effect and a significant storage by treatment interaction on TBA values were reported. Lipid oxidation peaked after 14 days storage and there was a decrease, consistent for both treatment groups, in TBA values in chops stored for 28 days vs 14 days. The TBA values were below the threshold value $(1.0 \mathrm{mg}$ malonaldehyde/ $\mathrm{kg}$ tissue) for detection of WOF (Boles and Parrish, 1990). Gray and Pearson (1987), summarizing previous research (Tarladgis et al., 1960; Greene and Cumuze, 1982), noted that rancid flavor was initially detected between TBA 0.5 and 2.0. The relatively low extent of lipid oxidation could be attributed to the cook-in-bag process, which rcmoved oxygen by vacuum packaging prior to cooking. Previous research has also supported the use of vacuum packaging as a means of reducing lipid oxidation in precooked pork (Jones et al., 1987; Boles and Parrish, 1990).

Sensory characteristics of precooked chops from control pigs and those supplemented with vitamin $\mathrm{E}$ were not significantly different during storage (Table 1). Significant storage (7 days through 56 days) effects existed for juiciness and off-flavor intensity, and treatment by storage interaction was significant for juiciness. All values for tenderness, pork-flavor intensity and off-flavor intensity fell within an acceptable range (we assumed that sensory values $>7.5$ were acceptable). Our findings indicated that under these processing and storage conditions, precooked chops could be successfully stored for $\geq 56$ days.

Cooking losses/storage losses were not different $(P>0.05)$ for VITE chops and CON chops throughout storage (Fig. 2). Time of storage had a significant effect on weight losses; however, no consistent trend was observed over duration of storagc. Reheating losses were not different $(P>0.05)$ between the two treatment groups at different storage times (data not presented in tabular form).

No differences $(\mathrm{P}>0.05)$ in TPC were found between treatments at any given storage time, but during the storage period, counts increased $(P<0.05)$ by $\approx$ one $\log$ (Table 2 ). According to Ayres (1955), typical spoilage occurs at bacterial levels $10^{7}$ $\leq 10^{8} \mathrm{CFU} / \mathrm{g}$. The TPC values we observed throughout storage were far below $10^{7}$ indicating that, by cook-in-bag processing, precooked longissimus chops could be stored for $\geq 56$ days.

\section{Precooked roast study}

Percentage moisture was lower $(\mathrm{P}<0.05)$ in muscles of VITE roasts compared to that in CON roasts while lipid levels were similar in the roasts from the two treatments (data not presented in tabular form). Although the difference in percentage moisture was significant, the magnitude of the difference $(73.57 \%$ compared to $72.63 \%$ ) was very small. Treatment $\mathrm{pH}$ values were not different $(\mathrm{P}>0.05)$, and $\mathrm{pH}$ changes over storage were minimal (data not presented in tabular form). 
Over the entire storage, TBA values were consistently lower $(\mathrm{P}<0.05)$ for VITE roasts than for CON roasts (Fig. 3). The magnitude of these differences was greatest at 0 days, 7 days, and 14 days storage. A storage effect and treatment by storage interaction were also observed $(P<0.05)$. The trends in lipid oxidation in the precooked roast study were similar to those in the precooked chop study. Only CON roasts stored 14 days had TBA values above the threshold for detection of WOF. These results indicate that precooking under vacuum and then storing under vacuum could minimize lipid oxidation over an extended period of time and that supplementation of vitamin $E$ to the live animal could be used to further assure reduced lipid oxidation. The results revealing relatively low TBA values for the entire storage period in both treatment groups were similar to those by Jones et al. (1987) and Boles and Parrish (1990) who attributed limited lipid oxidation during extended storage to vacuum packaging prior to precooking.

Sensory characteristics of precooked roasts from pigs fed CON or VITE diets were compared (Table 3). Off-flavor intensity scores, which indicate degree of WOF, were consistently lower $(\mathrm{P}<0.05)$ for VITE roasts than for CON roasts. A storage effect was found for off-flavor intensity $(P<0.05)$. Differences existed in taste-panel tenderness scores between treatments $(P<0.05)$. However, no previous research on feeding supplemental vitamin $\mathrm{E}$ to pigs has indicated differences in tenderness. A significant storage effect was observed for juiciness which tended to decrease as storage time increased. Juiciness scores were lowest for roasts stored 28 days. The magnitude of differences between VITE and CON roasts for off-flavor intensity scores as well as the acceptability level of these values (acceptable sensory scores $>7.5$ ) reflect the low TBA values. These results indicate that precooked roasts, prepared and stored under such conditions, have acceptable sensory characteristics after storage for $\geq 56$ days, and that adding supplemental vitamin $E$ to the swine diet would help insure minimal detection of off-flavors.

Cooking/storage losses were consistently lower $(P=0.05)$ for VITE roasts than for CON roasts (Fig. 4). Reheating losses were not different $(P>0.05)$ between the two groups (data not presented in tabular form). Previous investigators have reported that vitamin $\mathrm{E}$ supplementation of swine diets significantly lowered storage drip-loss of fresh pork chops (Asghar et al., 1991; Monahan et al., 1992a). Buckley and Morrissey (1992) speculated that $\alpha$-tocopherol molecules interacted with molecules in the cell membrane lipid bilayer and influenced the fluidity and integrity of the membrane. We could not conclude whether biochemical mechanisms involved in reducing storage loss were the same for precooked pork as those for fresh pork.

Significant treatment and storage effects and interactions between them were observed for TPC values (Table 2), which were higher for VITE roasts than for CON roasts at 0 days and 14 days storage. However, no consistent storage effects were detected and maximum counts did not exceed $3.0 \mathrm{log} \mathrm{CFU} / \mathrm{g}$. As with precooked chops, TPC values for precooked roasts were well below TPC levels at which products are considered spoiled.

Overall, our results suggested that cook-in-bag technology could be used to store precooked pork chops and roasts for at least 56 days. During this storage period, lipid oxidation and microbial growth could be minimized and sensory characteristics could be maintained at acceptable levels. Supplsmentation of vitamin $\mathrm{E}$ in the swine diet during the growing/firishing period can help minimize lipid oxidation in precooked pork.

\section{REFERENCES}

Ajuyah, A.O., Ahn, D.U., Hardin, R.T., and Sim, J.S. 1993. Dietary antioxidants and storage affect characteristics of $\omega-3$ fatty acid enriched broiler chicken meats. J. Food Sci. 58: 43-46,61.

AOAC. 1990. Official Methods of Analysis, 15th ed, Association of Official Analytical Chemists, Washington, DC.

Asghar, A., Gray, J.I., Booren, A.M., Gomaa, E.A., Abouzied, IM.M., Miller, E.R., and Buckley, D.J. 1991. Effects of supranutritional dietary vitamin $\mathrm{E}$ levels on subcellular deposition of alpha-tocopherol in the muscle and on pork quality. J. Sci. Food Agric. 57: 31-41.

on pork quality. J. Sci. Food Agric. $57: 31-41$.
Ayres, J.C. 1955 . Microbial implications in the handling, slaughtering and dressing of meat animals. Adv. Food Res. 6: 109-161.

Boles, J.A. and Parrish, F.C. Jr. 1990. Sensory and chemical characteristics of precooked microwave-reheatable pork roasts. J. Food Sci. 55: $618-620$. Buckley, D.J. and Morrissey, P.A. 1992. Pork, Ch. 3, in Vitamin E and Meat Quality, p. 13-21. Roche Animal Production Highlights. Basel, Switzerland.

Cannon, J.E., Morgan, J.B., Schmidt, G.R., Tatum, J.D., Sofos, J.N., Smith, G.C., Delmore, R.J., and Williams, S.N. 1995. Growth and fresh-meat quality characteristics of pigs supplemented with vitamin E. J. Anim. Sci. (In press).

Coelho, M.B. 1991. Functions of vitamin E. In Vitamin. E in Animal Nutrition and Management-A BASF Reference Manual, M.B. Ccielho (Ed.), p. 11-17. BASF Corporation, Parsippany, NJ

Cross, H.R., Leu, R., and Miller, M.F. 1987. Scope of warmed-over flavor and its importance to the meat industry. In Warmed-Over Flavior of Meat, $p$. 1-18, A.J. St. Angelo and M.E. Bailey (Ed.). Academic Press, Inc., Orlando, FL.

Gray, J.I. and Pearson, A.M, 1987. Rancidity and warmed-over flavor. Adv. Meat Res. 3: 221-269.

Greene, B.E. and Cumuze, T.H. 1982. Relationship between 'TBA numbers and inexperienced panelists' assessments of oxidized flavor in cooked beef. J. Food Sci. 47: 52-54,58.

Jones, S.L., Carr, T.R., and McKeith, F.K. 1987. Palatability and storage characteristics of precooked pork roasts. J. Food Sci. 52: 27i2-281,285.

Lin, C.F., Gray, J.I., Asghar, A., Buckley, D.J., Booren, A.M., and Flegal, C.J. 1989. Effects of dietary oils and alpha-tocopherol supplementation on lipid composition and stability in broiler meat. J. Food Sci. 54: 1457-1460, lipid 1484 .

1484.
Monahan, F.J., Buckley, D.J., Gray, J.I., Morrissey, P.A., Asફ̧har, A., Hanrahan, T.J., and Lynch, P.B. 1990a. Effect of dietary vitamin E on the stability of raw and cooked pork. Meat Sci. 27: 99-108

Monahan, F.J., Buckley, D.J., Morrissey, P.A., Lynch P.B., und Gray, J.I. $1990 \mathrm{~b}$. Effect of dietary $\alpha$-tocopherol supplementation on $\alpha$-t ocopherol levels in porcine tissues and on susceptibility to peroxidation. Food Sci. Nutr. 42F: 203-212.

Monahan, F.J., Asghar, A., Gray, J.I., Buckley, D.J., and M.orrissey, P.A.

Monahan, F.J., Asghar, A., Gray, J.I., Buckley, D.J., and Morrissey, P.A.
1992a. Influence of dietary vitamin E (alpha-tocopherol) on colour stability of pork chops. Proc. Intl. Congr. Meat Sci. Technol. 38: 543-546.

Monahan, F.J., Gray J.I., Booren, A.M., Miller, E.R., Buckley, D.J., Morrissey, P.A., and Gomaa, E.A. 1992b. Influence of dietary treatment on lipid and cholesterol oxidation in pork. J. Agric. Food Chem. 40: 1310-1315.

Raharjo, S., Sofos, J.N., and Schmidt, G.R. 1993. Solid-phase acid extraction improves thiobarbituric acid method to determine lipid oxilation. $J$ Food Sci. 58: 921-924, 932

Salih, A.M., Smith, D.M. Price, J.F., and Dawson, L.E. 198\%' Modified extraction 2-thiobarbituric acid method for measuring lipid oxidation in poultraction 2-thiobarbituric acid m

SAS Institute, Inc. 1986. SAS User's Guide: Statistics, 1986 Edition. SAS Institute, Inc., Cary, NC.

Tarladgis, B.G., Watts, B.M., Younathan, M.T., and Dugan, L.R. Jr. 1960. A distillation method for the quantitative determination of inalonaldehyde in rancid foods. J. Am. Oil Chem. Soc. 37: 44-48.

Tims, M.J. and Watls, B.M. 1958. Protection of cooked meits with phosphates. Food Technol. 12: 240-243.

phates. Food Technol. 12: 240-243.
Ms received 2/2/95; revised 7/16/95; accepted 7/22/95.

This work was supported in part by Hoffman-LaRoche, Inc. and by the Colorado Agricultural Experiment Station. 